\title{
A Printed Antenna Design with Defected Ground Structure for Multiband Applications
}

\author{
Maie A. Gaber ${ }^{1,}{ }^{*}$, Faten Fouad ${ }^{2}$, Ashraf Yahia $^{3}$, Mostafa El-Aasser ${ }^{4}$, Nasr Gad $^{5}$ \\ $1^{*}$ Ain Shams University, Faculty of Science, Department of Physics, Cairo, Egypt (ORCID: 0000-0003-3432-1913), maiegaber@sci.asu.edu.eg \\ ${ }^{2}$ Ain Shams University, Faculty of Science, Department of Physics, Cairo, Egypt, (ORCID: 0000-0002-9718-9481), fatenfouad_p@sci.asu.edu.eg \\ ${ }^{3}$ Ain Shams University, Faculty of Science, Department of Physics, Cairo, Egypt, (ORCID: 0000-0003-1998-4647), ayahia@sci.asu.edu.eg \\ ${ }^{4}$ Ain Shams University, Faculty of Science, Department of Physics, Cairo, Egypt, (ORCID: 0000-0003-3010-1905), Elaasser@gmail.com \\ ${ }^{5}$ Ain Shams University, Faculty of Science, Department of Physics, Cairo, Egypt, (ORCID: 0000-0002-4175-877X), ngad@sci.asu.edu.eg
}

(1st International Conference on Applied Engineering and Natural Sciences ICAENS 2021, November 1-3, 2021)

(DOI: 10.31590 /ejosat.1020955)

ATIF/REFERENCE: Gaber, M. A., Fouad, F., Yahia, A., El-Aasser, M. \& Gad, N. (2021). A Printed Antenna Design with Defected Ground Structure for Multiband Applications. European Journal of Science and Technology, (28), 1528-1533.

\begin{abstract}
In this paper, the design and analysis of a printed antenna based on a defected ground structure for multiband applications is introduced. The proposed antenna consists of two rectangular slots like an inverted stair. Different five strip lengths are in the area of an inverted stair slot. Four strips are equal in width and horizontally located inside the main two rectangular slots. The fifth strip is the smallest one in the middle of the structure in the ground plane. The microstrip line exists only on the front side plane and parallel to the fifth strip. The antenna is printed on a hydrocarbon ceramic substrate with a dielectric constant of 3.55 and a size $(40 \times 45 \times 1.524) \mathrm{mm}^{3}$. The proposed antenna is designed by using an electromagnetic simulator based on the finite element method. To verify the suggested approach, the multiband antenna is fabricated and tested. The simulation and measurement results indicate that the antenna has good input-impedance bandwidths $\left(\mathrm{S}_{11} \leq-10 \mathrm{~dB}\right)$ that extend in the range of 2 to $14 \mathrm{GHz}$. The six operating frequencies are $(2.58,6.03,6.25$, 7.89, 11.64, and 12.24) GHz. This antenna has good gains and high efficiencies at all resonance frequencies.
\end{abstract}

Keywords: Printed antenna; Multiband applications; Defected ground structure; Slot antenna

\section{Çoklu Bant Uygulamaları için Bozuk Zemin Yapısına Sahip Basılı Bir Anten Tasarımı}

$\ddot{\mathbf{O z}}$

Bu çalışmada, çok bantlı uygulamalar için kusurlu bir zemin yapısına dayalı basılı bir antenin tasarımı ve analizi tanıtılmaktadır. Önerilen anten, ters çevrilmiş bir merdiven gibi iki dikdörtgen yuvadan oluşur. Ters çevrilmiş bir merdiven yuvası alanında farklı beş şerit uzunluğu vardır. Dört şerit eşit genişliktedir ve ana iki dikdörtgen yuvanın içine yatay olarak yerleştirilmiştir. Beşinci şerit, yer düzleminde yapının ortasındaki en küçük şerittir. Mikroşerit çizgisi yalnızca ön yan düzlemde ve beşinci şeride paralel olarak bulunur. Anten, dielektrik sabiti 3.55 ve boyutu $(40 \times 45 \times 1.524) \mathrm{mm} 3$ olan bir hidrokarbon seramik substrat üzerine basılmıştır. Önerilen anten, sonlu elemanlar yöntemine dayalı bir elektromanyetik simülatör kullanılarak tasarlanmıştır. Önerilen yaklaşımı doğrulamak için çok bantlı anten üretilmiş ve test edilmiştir. Simülasyon ve ölçüm sonuçları, antenin 2 ila $14 \mathrm{GHz}$ aralığında genişleyen iyi giriş empedans bant genişliğine $(\mathrm{S} 11 \leq-10 \mathrm{~dB})$ sahip olduğunu göstermektedir. Altı çalışma frekansı $(2.58,6.03,6.25,7.89,11.64$ ve 12.24$) \mathrm{GHz}$ 'dir. $\mathrm{Bu}$ anten, tüm rezonans frekanslarında iyi kazanımlara ve yüksek verimliliğe sahiptir.

Anahtar Kelimeler: Basılı anten; Çoklu bant uygulamaları; Arızalı zemin yapısı; Yuva anteni. 


\section{Introduction}

Nowadays, wireless communication systems have progressed very rapidly and hence increased the need to provide antennas with a large bandwidth for multiband applications. Besides, devices are getting to be so small with monolithic microwave integrated circuit (MMIC) and compact antennas. Therefore, multiband antennas attracted a great interest in wireless services such as WI-FI, weather radar systems, long-term evolution (LTE), 4G, 5G, satellite TV, and so on. Each wireless system requires a large impedance bandwidth and a stable radiation pattern over its operating frequency range. The multiband antenna designs, which published in wireless communications are heading towards covering more than one resonance frequency band like the dual band [1], the triple band [2],[3], and quad band applications [4],[5]. On the other hand, printed antennas are popular candidates for providing multiband characteristics due to the lightweight features, low cost, and easy fabrication [6].

The popular printed antennas are as microstrip antennas, slot antennas, monopole antennas, and fractal antennas [7]. To design printed multiband antennas, different techniques are used such as defected ground structure (DGS), defected microstrip structure (DMS), band-notch, and meander line. A band notch was used to get a multiband antenna operating at four resonance frequencies in the region (2-8) GHz in [8]. A meander line was used as a DGS in [9] to operate at four resonance frequencies in the region (17.5) GHz. DMS was applied in [10] to generate three bands for WiMAX, WLAN, and X-band applications. In [11], triple notch bands were applied to resonate in the region $(2-12) \mathrm{GHz}$ for WBAN applications. Printed slot antenna with slot defects on the ground plane operating at five bands has been successfully designed in [12]. DGS and DMS techniques are reported in [13] as defected structures to design a microstrip multiband antenna in mirror stairs shaped that resonates at six frequencies.

In this paper, the proposed multiband printed antenna design is based on the DGS technique by etching two rectangular slots with different dimensions attached with each other in the ground plane. Four horizontal rectangular strips are added inside the main slots, each two strips with different lengths, and narrow vertical strip with $0.5 \mathrm{~mm}$ width located under and parallel to the microstrip line. While on the top of the substrate, there is a microstrip line in the center only. The proposed antenna is designed and simulated using an electromagnetic simulator based

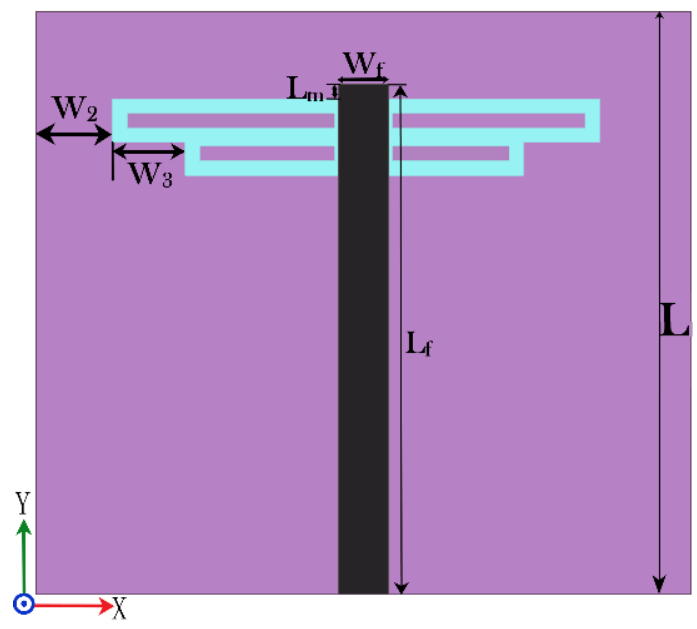

(a) on FEM. Six resonance simulated frequencies of $(2.58,6.03,6.25$, 7.89, 11.62 and 12.24) $\mathrm{GHz}$ are obtained. The first band (2.442.79) $\mathrm{GHz}$ covers digital multimedia broadcasting (DMB) and weather radar applications. The $5 \mathrm{G}$ sub-7GHz and Wi-Fi applications are covered by the second and third resonance frequencies which are found in the band (5.88-6.39) GHz. The band (7.5-8.25) GHz is suitable for ITU-8 GHz band communication services. The last two bands integrated in one band in frequency range (11.27-12.69) GHz is suitable for satellite TV application.

\section{Analysis of The Proposed Antenna}

The geometry of the proposed printed multiband antenna is shown in Fig .1. The proposed antenna has a RO4003c substrate with a size $(45 \times 40 \times 1.52) \mathrm{mm}^{3}$, a dielectric constant $\left(\varepsilon_{\mathrm{r}}=3.55\right)$, and a return loss $(\tan \delta=0.0027)$. On the substrate top, there is only a microstrip line of feeding length $\left(\mathrm{L}_{\mathrm{f}}\right)$ and width $\left(\mathrm{W}_{\mathrm{f}}\right)$. On the other side, the bottom of the substrate, there is a ground plane that consists of two defected rectangular slots connected with each other, and five strips designed in the rectangular slots. The larger slot is shifted to right by $1 \mathrm{~mm}$ from the center comparable to the left slot that is around the vertical narrow strip with $0.5 \mathrm{~mm}$ width. The second smaller rectangular slot is shifted to the left by 1.25 $\mathrm{mm}$ from the center with respect to the left slot around the vertical narrow strip with $0.5 \mathrm{~mm}$ width. The horizontal strips in the ground are not equal in length and all of them with $1 \mathrm{~mm}$ away from the slots' boundary. In Table 1, all parameters of the proposed printed antenna are shown.

Table 1. The designed parameters of the proposed antenna

\begin{tabular}{|c|c|c|c|}
\hline Parameter & $\begin{array}{c}\text { Value } \\
(\mathbf{m m})\end{array}$ & Parameter & $\begin{array}{c}\text { Value } \\
(\mathbf{m m})\end{array}$ \\
\hline $\mathrm{L}$ & 40 & $\mathrm{~S}_{2}$ & 2.25 \\
\hline $\mathrm{W}$ & 45 & $\mathrm{Ls}_{2}$ & 23.25 \\
\hline $\mathrm{L}_{\mathrm{f}}$ & 35 & $\mathrm{M}_{1}$ & 1 \\
\hline $\mathrm{W}_{\mathrm{f}}$ & 3.4 & $\mathrm{M}_{2}$ & 1 \\
\hline $\mathrm{L}_{\mathrm{m}}$ & 1 & $\mathrm{M}_{3}$ & 0.5 \\
\hline $\mathrm{W}_{1}$ & 4 & $\mathrm{~W}_{2}$ & 5.25 \\
\hline $\mathrm{S}_{1}$ & 3 & $\mathrm{~W}_{3}$ & 5 \\
\hline $\mathrm{Ls}_{1}$ & 33.5 & & \\
\hline
\end{tabular}

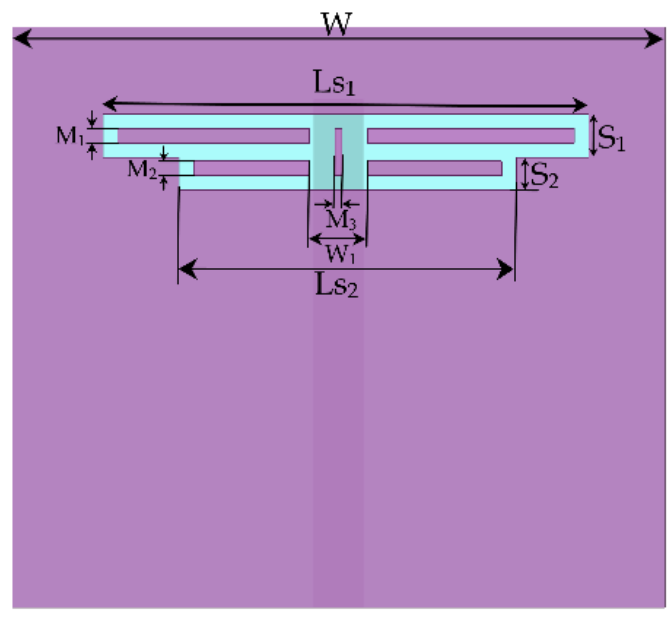

(b)

Fig. 1: The proposed antenna (a) front view (b) back view. 
The performance of antenna was optimized using HFSS simulator based on FEM [14]. Fig. 2 shows the reflection coefficient of the proposed antenna. The effect of the length $\left(\mathrm{L}_{\mathrm{f}}\right)$ and width $\left(\mathrm{W}_{\mathrm{f}}\right)$ of feeding line on the antenna's performance is depicted in Fig. 2(a) and (b) respectively, causing a shift in certain resonance frequency and enhancing the other. From Fig. 2(c), it can be seen that increasing the distance between horizontal strips $\left(\mathrm{W}_{1}\right)$, decreased the resonant frequency. The simulated reflection coefficient response with different values of small slot width $\left(\mathrm{S}_{2}\right)$ is shown in Fig. 2(d). Fig. 2(e) shows that the width of vertical strip (S2) under the transmission line is almost acting only on the first resonance frequency. The sequence of the proposed design by removing the strips is shown in Fig. 2(f): At first, design A, when removing the two small horizontal strips from the proposed design that has a significant effect at higher frequencies. Then, in design $\mathrm{B}$, the smallest strip which under and parallel to the transmission line is removed. Finally, the biggest horizontal strips are taken off in design $\mathrm{C}$. when removing the two small horizontal strips from the proposed design that has a significant effect at higher frequencies. Then, in design $\mathrm{B}$, the smallest strip which under and parallel to the transmission line is removed. Finally, the biggest horizontal strips are taken off in design $\mathrm{C}$

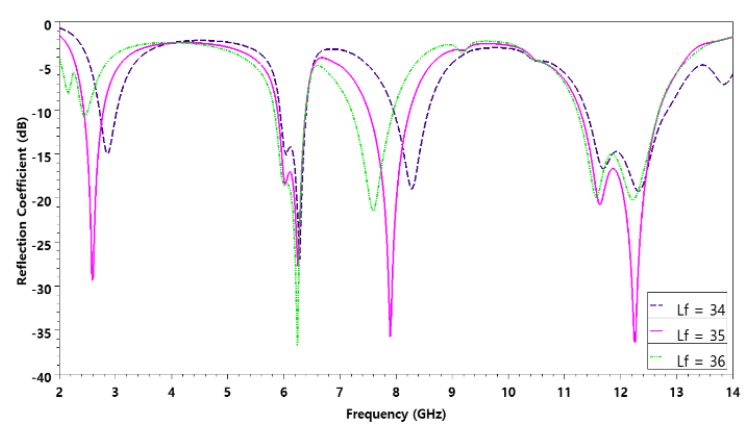

(a)

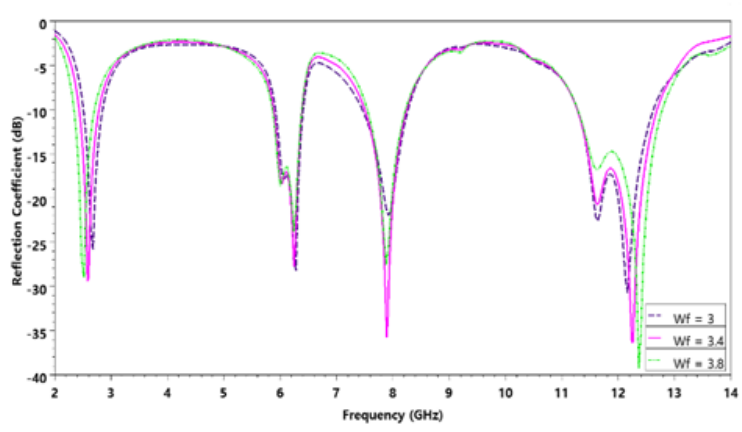

(b)

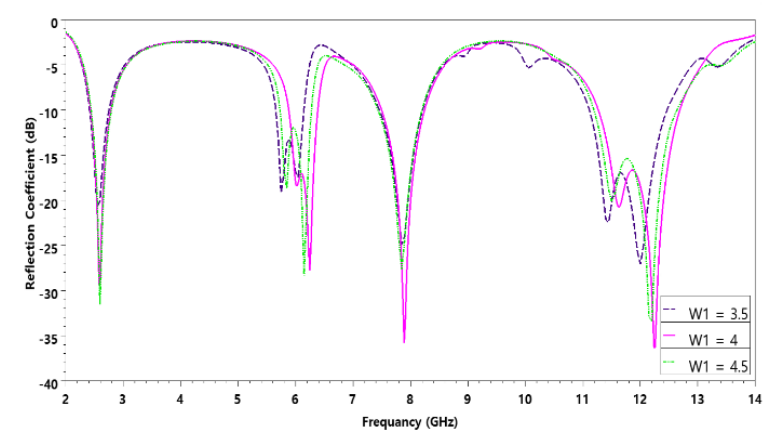

(c)

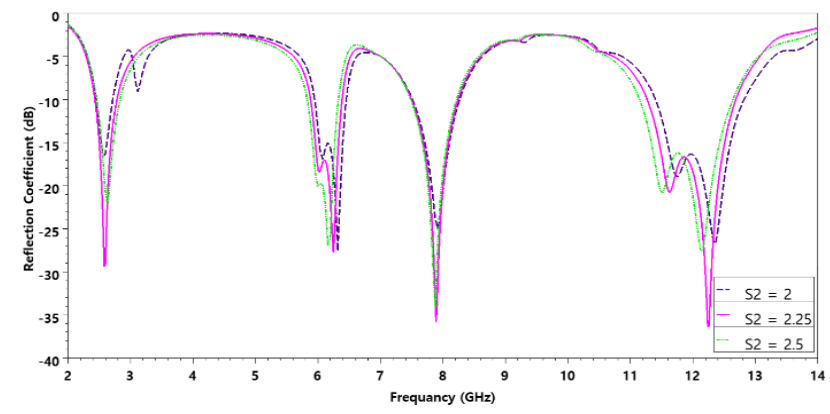

(d)

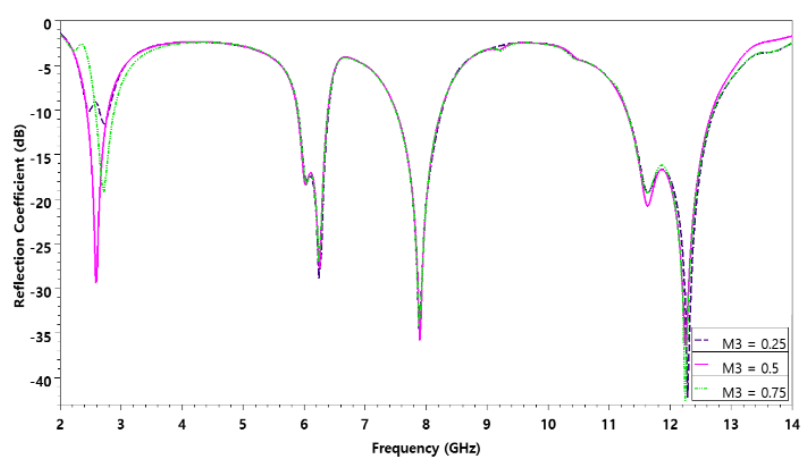

(e)

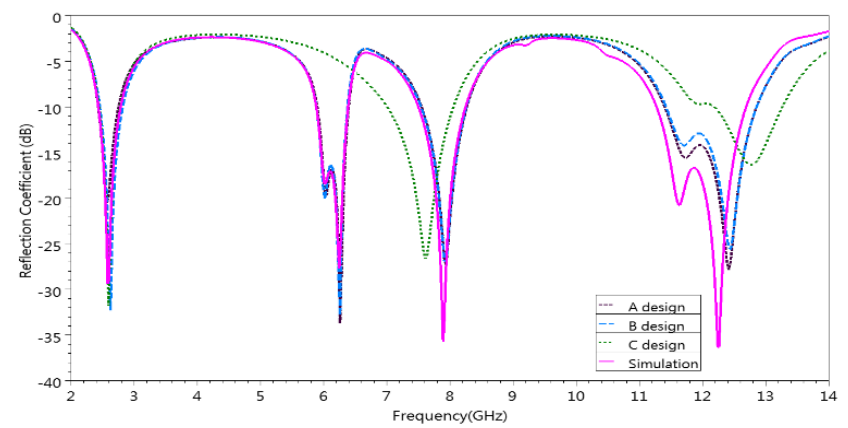

(f)

Fig. 2: The simulated reflection coefficient for the proposed antenna with different configurations: (a) length of feeder $\left(\mathrm{L}_{\mathrm{f}}\right)$, (b) width of feeder $\left(\mathrm{W}_{\mathrm{f}}\right),(\mathrm{c})$ the distance between horizontal strips $\left(\mathrm{W}_{1}\right),(\mathrm{d})$ width of small slot $\left(\mathrm{S}_{2}\right)$, (e) width of vertical strip $\left(\mathrm{M}_{3}\right)$, (f) sequence of designed proposed antenna.

From the reflection coefficient results, the best performance of the proposed antenna design parameters are as follows: length of feeder $\left(\mathrm{L}_{\mathrm{f}}\right)$, width of feeder $\left(\mathrm{W}_{\mathrm{f}}\right)$, distance between the horizontal strips $\left(\mathrm{W}_{1}\right)$, width of small slot $\left(\mathrm{S}_{2}\right)$, and width of vertical strip $\left(\mathrm{M}_{3}\right)$ are $(35,3.4,4,2.25$, and 0.5$) \mathrm{mm}$, respectively.

\section{Results and Discussion}

The proposed multiband printed antenna performance was discussed in the previous section. The proposed antenna was fabricated, and the reflection coefficient was measured by using Rohde \& Schwarz ZVB 20 Vector Network Analyzer. The front and back side of the fabricated antenna are presented in Fig. 3. To achieve multiband operation for the slot printed antenna, the slot length of each radiating element must be around $\lambda_{\mathrm{g}} / 2$ [15]

$$
\lambda_{g}=\frac{c}{f \sqrt{\varepsilon_{e}}}
$$


where $\varepsilon_{\mathrm{e}}$ is the effective dielectric constant

$$
\varepsilon_{e} \approx \frac{\left(\varepsilon_{r}+1\right)}{2}
$$

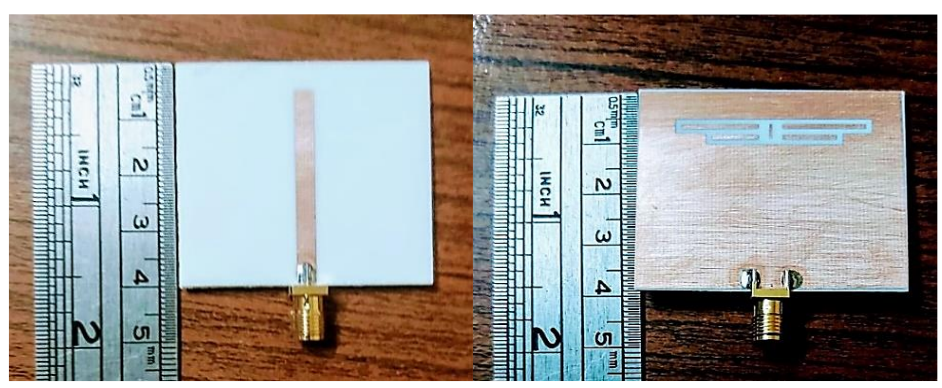

Fig. 3: The fabricated antenna (a) front view (b) back view.

The simulated and measured results of the reflection coefficient $\left(S_{11}\right)$ are shown in Figure 4. A good agreement between the simulation and measurement results is obtained in region from 2 to $14 \mathrm{GHz}$. The measured impedance bandwidths achieved are 2.537-2.918 GHz with a bandwidth of $0.381 \mathrm{GHz}(13.97 \%)$, two integrated bandwidths around $6.149 \mathrm{GHz}$ with $\left(\mathrm{S}_{11}=-13.377 \mathrm{~dB}\right)$ in the range of (5.899-6.149) GHz with a bandwidth of $0.25 \mathrm{GHz}$ (4.15\%), (6.149-6.412) GHz with bandwidth of $0.263 \mathrm{GHz}$ $(4.187 \%)$. The last two bands are considered as a wideband of (5.899-6.412) GHz with a bandwidth of $0.513 \mathrm{GHz}(8.334 \%)$ for $\left|\mathrm{S}_{11}\right| \leq-10 \mathrm{~dB},(7.815-8.353) \mathrm{GHz}$ with a bandwidth of 0.538 $\mathrm{GHz}(6.655 \%)$, two integrated bandwidths around $12.365 \mathrm{GHz}$ with $\left(\mathrm{S}_{11}=-12.3 \mathrm{~dB}\right)$ in the range of $(11.12-12.365) \mathrm{GHz}$ with a bandwidth of $1.245 \mathrm{GHz}(10.6 \%),(12.365-13.059) \mathrm{GHz}$ with a bandwidth of $0.694 \mathrm{GHz}(5.453 \%)$, the two bands are considered as a wideband of (11.12-13.059) $\mathrm{GHz}$ with a bandwidth of 1.939 $\mathrm{GHz}(16.039 \%)$ for $\left|\mathrm{S}_{11}\right| \leq-10 \mathrm{~dB}$. A comparison of the $\mathrm{S}_{11}$ data for all the operating frequencies is summarized in Table 2.

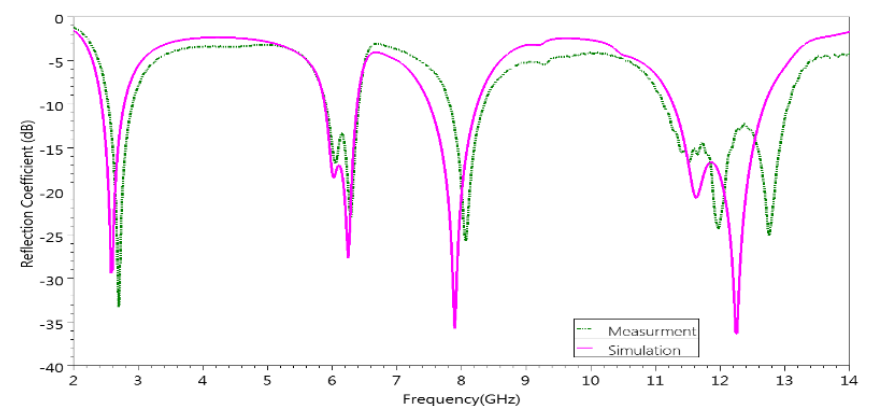

Fig. 4: The simulated and measured reflection coefficient of the proposed antenna.
The simulated peak gains and efficiency of the proposed printed antenna, fed by a microstrip line, are plotted in Fig. 5(a) and $5(\mathrm{~b})$, respectively.

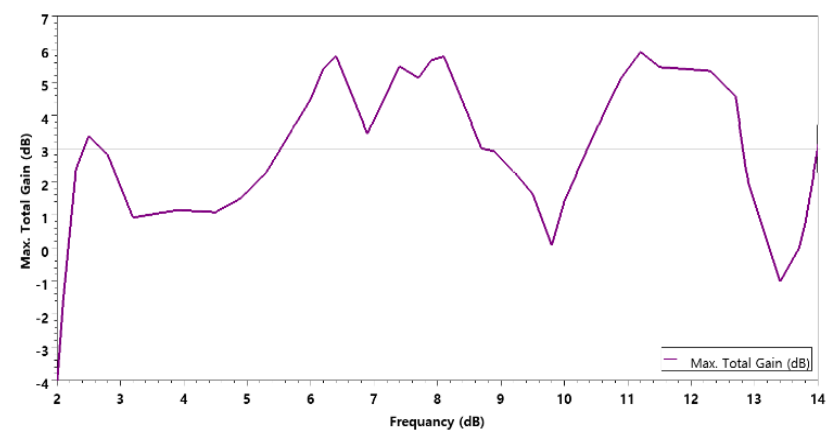

(a)

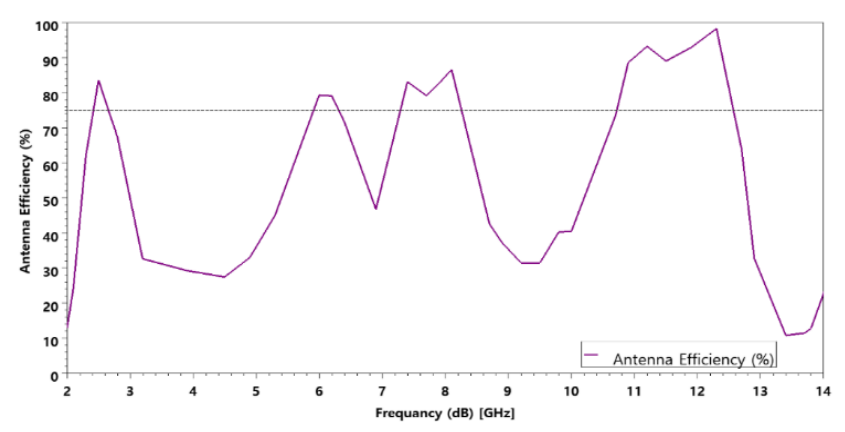

(b)

Fig. 5: (a) The simulated gain of the proposed antenna, (b) The simulated efficiency of the proposed antenna

The simulated results of the gain show the values $(3.22,4.62$, $5.5,5.63,5.43$ and 5.34) $\mathrm{dB}$ at $(2.58,6.03,6.25,7.89,11.62$, and 12.24) $\mathrm{GHz}$, respectively. The simulated antenna efficiency at the operating frequencies is given by $(79.29,79.28,77.24,82.48$, 90.35 , and 97.70$) \%$ at $(2.58,6.03,6.25,7.89,11.62$, and 12.24$)$ $\mathrm{GHz}$, respectively.

The simulated radiation patterns of the proposed antenna for the E-plane (Y-Z plane) and the H-plane (X-Z plane) are shown in Fig. 6.

Table 2: Simulated and measured return losses of the proposed printed antenna

\begin{tabular}{|l|l|l|l|l|l|l|l|}
\hline $\begin{array}{l}\text { Resonance } \\
\text { Frequency } \\
\text { (GHz) }\end{array}$ & Simulation & 2.584 & 6.03 & 6.25 & 7.892 & 11.616 & 12.238 \\
\cline { 2 - 7 } & Measurement & 2.703 & 6.053 & 6.288 & 8.063 & 11.964 & 12.756 \\
\hline $\begin{array}{l}\text { S11(dB) at } \\
\text { Resonance } \\
\text { Frequency }\end{array}$ & Simulation & -29.387 & -18.48 & -27.72 & -35.775 & -20.739 & -36.31 \\
\cline { 2 - 8 } & Measurement & -33.255 & -16.797 & -23.013 & -25.681 & -24.327 & -25.08 \\
\hline $\begin{array}{l}\text { Frequency } \\
\text { Region (GHz) }\end{array}$ & Simulation & $2.44-2.79$ & $5.88-6.109$ & $6.109-6.39$ & $7.50-8.25$ & $\begin{array}{l}11.27- \\
11.857\end{array}$ & $\begin{array}{l}11.857- \\
12.69\end{array}$ \\
\cline { 2 - 8 } & Measurement & $2.537-$ & $\begin{array}{l}5.899- \\
6.149\end{array}$ & $\begin{array}{l}6.149- \\
6.412\end{array}$ & $\begin{array}{l}7.815- \\
8.353\end{array}$ & $\begin{array}{l}11.12- \\
12.365\end{array}$ & $\begin{array}{l}12.365- \\
13.059\end{array}$ \\
\hline
\end{tabular}



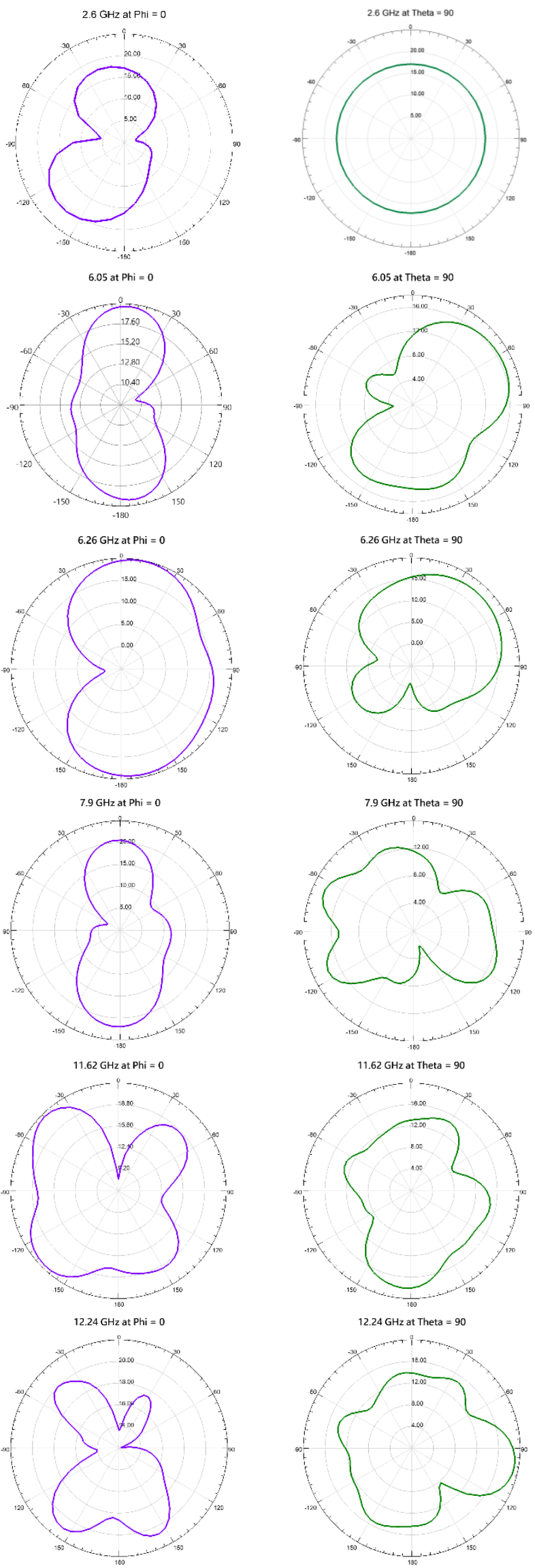

Fig. 6: The simulated radiation patterns of the proposed multiband printed antenna. (a)E-plane at 2.58, 6.03, 6.25, 7.89, 11.62 and $12.24 \mathrm{GHz}$. (b) H-plane at $(2.54,6.03,6.25,7.89,11.62$ and 12.24) GHz.

\section{Conclusions}

A new multiband printed antenna is designed, simulated, fabricated, and measured. It has two rectangular slots as defected on the ground plane and five strips located inside the two slots. The proposed antenna operates at four bands, $(2.44-2.79,5.88$ 6.39, 7.5-8.25, 11.27-12.69) GHz. The designed antenna has been successfully simulated by using finite element method simulator. The antenna is fabricated on RO4003C substrate with dimension $(45 \times 40) \mathrm{mm}^{2}$ to verify the simulation results. The measured results showed a good agreement with the simulation results for the reflection coefficient. The simulated gain varies from 3.22 to $5.63 \mathrm{~dB}$ at the operating frequencies. The presented antenna has simulated efficiencies of $(79.29,79.28,77.24,82.48,90.35$, and $97.70) \%$, respectively. This makes the antenna design suitable for DMB, weather radar, 5G Sub-7GHz, Wi-Fi, ITU-8 GHz band communication, and satellite TV applications.

\section{References}

[1] Zhong, Zeng-Pei, et al. "Compact dual-band printed quadrifilar helix antenna for practical hand-held devices." International Journal of $R F$ and Microwave Computer-Aided Engineering 30.11 (2020): e22384.

[2] Khan, Tayyaba, and MuhibUr Rahman. "Wearable tri-band antenna for switching between WLAN and bluetooth for body centric wireless communication." Wireless Personal Communications 117.2 (2021): 1459-1470.

[3] Sun, Xu-Bao. "Design of a triple-band antenna based on its current distribution." Progress In Electromagnetics

[4] Research 90 (2020): 113-119. Yossry, Alaa, et al. "HybridShape Dielectric Resonator Antennas for Multiband Applications." 2021 International Conference on Electronic Engineering (ICEEM). IEEE, 2021.

[5] Modak, Sumon, Taimoor Khan, and Rabul Hussain Laskar. "Loaded UWB Monopole Antenna for Quad Band-Notched Characteristics." IETE Technical Review (2021): 1-9.

[6] Balanis, Constantine A. Antenna theory: analysis and design. John wiley \& sons, 2016.

[7] Pandey, Anil. Practical microstrip and printed antenna design. Artech House, 2019.

[8] Wang, Junjun, and Xudong He. "Analysis and design of a novel compact multiband printed monopole antenna." International Journal of Antennas and Propagation 2013 (2013).

[9] Patel, Riki, et al. "Low profile multiband meander antenna for LTE/WiMAX/WLAN and INSAT-C application." AEU-International Journal of Electronics and Communications 102 (2019): 90-98.

[10] Khaddaj Mallat, Nazih, and Amjad Iqbal. "Multi-band printed antenna for portable wireless communication applications." Progress In Electromagnetics Research 84 (2019): 39-46.

[11] Doddipalli, Srinivas, and Ashwin Kothari. "Compact UWB antenna with integrated triple notch bands for WBAN applications." IEEE Access 7 (2018): 183-190.

[12] Gad, Nasr H., and Matjaz Vidmar. "Design of a MicrostripFed Printed-Slot Antenna Using Defected Ground Structures for Multiband Applications." Applied Computational Electromagnetics Society Journal 33.8 (2018).

[13] Fouad, Faten, et al. "Design of a Mirror Stairs Multiband Microstrip Antenna Using Defected Structures." 2021 38th 
National Radio Science Conference (NRSC). Vol. 1. IEEE, 2021.

[14] ANSYS® Electromagnetics Student, ver. 2.2.1. online: Ansys | Engineering Simulation Software

[15] R. Garg, P. Bhartia, I. Bahl, and A. Ittipiboon, Microstrip Antenna Design Handbook. Artech House, Norwood, MA, 2001 